\title{
Performance of Recycled Concrete Made from Railway Sleeper: Experimental Study
}

\author{
Suharwanto $^{1 *}$, Wachid Hasyim ${ }^{1}$, and Yudha Prakasa ${ }^{1}$ \\ ${ }^{1}$ Wiralodra University, Indramayu, 45213, Indonesia \\ * Corresponding author: suharwanto.ft@unwir.ac.id
}

(Received: September 22 ${ }^{\text {nd }} 2021$; Accepted: October $6^{\text {th }} 2021$ )

\begin{abstract}
Concrete railway sleeper has been used in Indonesia since about 1990's. It has more advantage that is less maintenance, stabile, good quality, shapeable, onsite raw material, and higher loading ability [9$10,20-22]$. But It is prone to damage such as cracking and breaking during construction, so it is often thrown away as a solid waste that can contaminate the land and reduce soil fertility. Therefore, it should be utilized in order to be more useful that is used as recycle aggregate. The concrete waste that is taken from broken concrete railway sleeper will be crush as an aggregate as raw material in the concrete to substitute part or all of the normal concrete. It is called recycled aggregate and concrete that is made from recycled aggregate is called recycled concrete. Base on the testing of raw material, the recycled aggregate can be met to the specification as ASTM [1], so it can be used for concrete raw material. The compressive strength of recycled concrete results in a lower compressive strength of normal concrete at the same initial compressive strength. The strength value of recycled concrete decreased by about $1-17 \%$ for $25 \mathrm{MPa}$, and $10-18 \%$ for $30 \mathrm{MPa}$. Likewise, the tensile strength of recycled concrete decreased by around $2-13 \%$ for $25 \mathrm{MPa}$ and $7-22 \%$ for $30 \mathrm{MPa}$.
\end{abstract}

Keywords: concrete railway sleeper; compressive strength; recycled aggregate; recycled concrete; tensile strength

\section{Introduction}

In Indonesia, the railway was designed by Netherland government as a colonialist, but the realization of construction was built since 1864 in Java that is Solo-Yogyakarta [19 - 21, 24]. The railway was made by steel and the sleeper was produced by wood (Figure 1.a) or steel (Figure 1.b). The wood must be selected material that is elastic and good wooden grain, and the steel is common material that is mill steel. The wood is very difficult to find now, because the jungle has been cleared and looted by community, and the other placed has protected by government. And the steel price has very expensive, so the railway construction will become high price. Base on the both problems they are wood scarcity and steel rail high price sleeper material, the alternative railway sleeper material must be found the solution. It is concrete railway-sleeper (Figure 1.c) that is precast concrete $[9-10,19-21,24]$.

Precast concrete railway sleepers have been used since the 1990s, the first being the BandungJakarta route $[20-22,24]$. The precast concrete is usually pre-tension prestressed system that is fabricate in workshop $[26,30]$. The companies that produce the precast concrete railway sleeper in Indonesia are WIKA Beton, Waskita Beton Precast, PT. Tjakrindo Mas, and other companies. The company must be produced and followed to code or standard [30], and other code [19-21]. 
The minimum concrete strength of precast concrete sleeper is K-500 (about $f^{\prime} c=41 \mathrm{MPA}$ ) and the minimum tensile strength of prestressed tendon is $17,000 \mathrm{~kg} / \mathrm{cm}^{2}$ (about $1,700 \mathrm{MPA}$ ) $[21,26]$.

The precast concrete railway sleeper that has produced in workshop will be mobilized to site by truck or trailer transportation. It also will be loading and unloading by crane or other lifting equipment that compatible in the field conditions. The precast concrete is often crack, break or damage when it is arrived on the field. The damage precast concrete is rejected, because it is not proper to the requirement and it became waste material. It usually throw out from the field and it affect to the fertility soil that is solid waste or land contamination. The concrete solid waste is also only land fill that is not economical. Base on the both problems, the concrete waste that takes rom damaging precast concrete railway sleeper will be used for aggregate in the concrete. The aggregate is called recycled aggregate as substitute a part of normal coarse aggregate or crush rock because the concrete is classified high strength concrete. The aggregate can be predicted high strength aggregate caused by high strength resources. It should be tested to verify the actual strength of recycled concrete. Furthermore, experimental study will be execute the research. The implication of this research is a reduce and increasing economic value the solid waste (concrete waste).

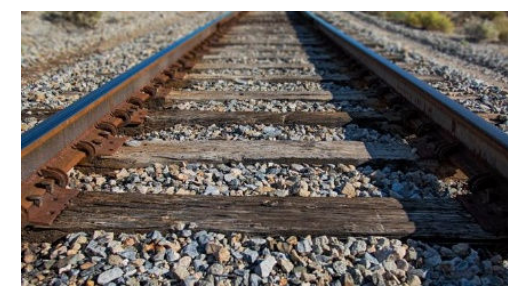

a) Wooden Railway Sleeper

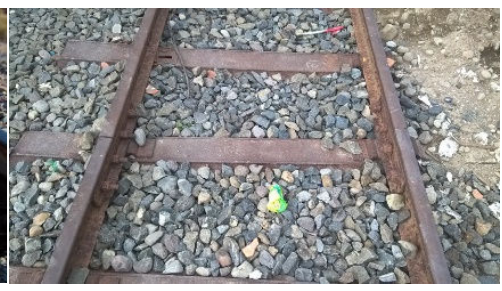

b) Steel Railway Sleeper

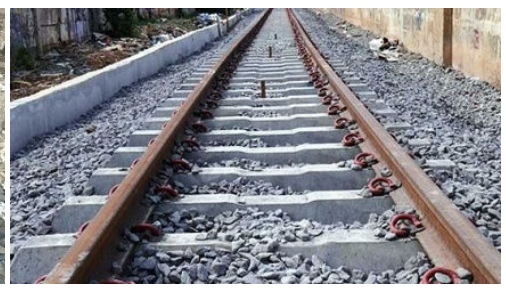

c) Concrete Railway Sleeper

Fig. 1. Type of Railway Sleeper [21, 26]

\section{Literature Study}

Recycled concrete aggregate is an aggregate that is made from concrete waste material to became aggregate as replacing or substitute the normal or crush rock aggregate and fine aggregate. The concrete waste will be crushed as aggregate in order to make a concrete [2-8, 11-13, 23, 27-29, $31-37]$. The concrete that makes from recycle aggregate is called recycle concrete [2-8, 11-13, 23, 27-29, 31-37]. Base on the several researches, the compressive strength result of recycled concrete have lower then normal concrete (that use normal aggregate). Decreasing of recycled concrete compressive strength are about $5-45 \%$ then normal concrete $[2-5,11-12,31]$ and it depends on the recycled aggregate as resources of recycled concrete. If the recycled aggregate as a row material of recycled concrete are low strength, so the concrete recycled compressive strength result are low strength [2-5,11-12, 31].

Test result of compressive strength recycled concrete that the recycled aggregate is taken from high strength concrete are obtained a compressive strength decreasing about $13.1-67.2 \%$ for $25 \%$, $17.6-72.0 \%$ for $50 \%, 24.3-74.6 \%$ for $75 \%$ and $6.5-71.1 \%$ for $100 \%$ recycled aggregate content. $[5,31]$. The other tests result of research that is $30 \mathrm{MPa}$ for the initial compressive strength design are decreasing $10 \%$ for $25 \%, 22 \%$ for $50 \%, 32 \%$ for $75 \%$ and $45 \%$ for $100 \%$ recycled aggregate content $[31,37]$. Usually, the researches of recycled concrete represent a similar result that the compressive strengths decrease from the normal concrete initial design. It may be caused by weak bonding and interlocking between aggregate and cement paste, so the advance research needs to be done to find out the interlocking in the micro cracking or internal bonding [31]. 


\section{Experintal Program}

\subsection{Concrete Raw Material Testing}

Raw material of normal and recycled aggregate should be tested to get a characteristic of it. All raw materials testing will refer to standard that is ASTM C-136-06 [3]. The normal aggregates are coarse and fine aggregate and the recycled aggregate is only coarse aggregate. All of aggregates should be attend to specification in order to able for concrete material because the mix design of concrete strength needs a special characteristic such as gradation, specific gravity, water content and others to get a weight proportion in the concrete.

One of the test is save analysis that will be presented in the figure 2. It is illustrated distribution of granular that will be filled all of the space in the concrete volume in order to be solid. The others testing are presented in the Table 1, they are specific gravity, water content, abrasion percentage, and other characteristic. Those are used for proportion weight calculation in the concrete that is called concrete mix design. The test result all aggregates can be used for raw material of concrete, because they meet to ASTM specification that a standard of concrete no exception for recycled aggregate.

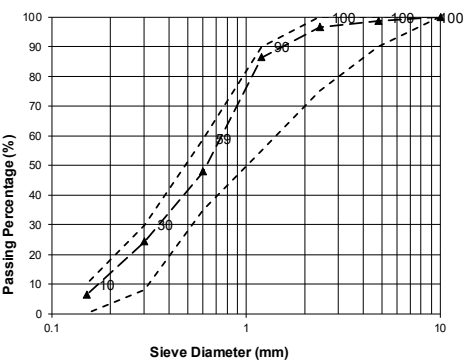

a) Normal Fine Aggregate

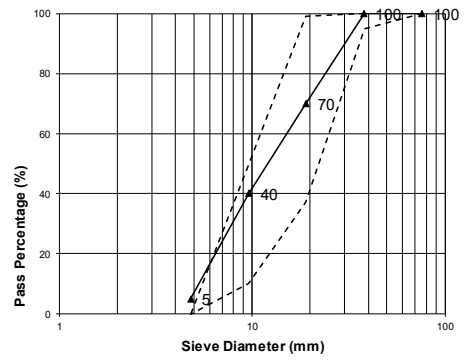

b) Normal Coarse Aggregate

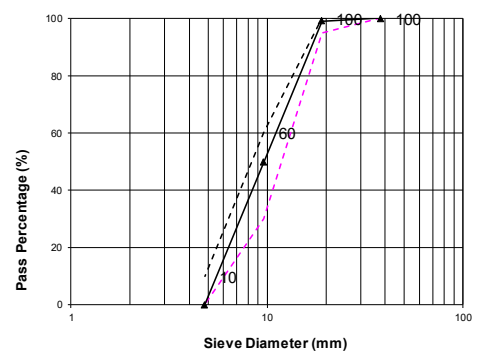

c) Recycled Coarse Aggregate

Fig. 2. Sieve Analysis of Fine and Coarse Aggregate

Table 1. Aggregate Characteristic

\begin{tabular}{lccc}
\hline \multicolumn{1}{c}{ Description of Testing } & $\begin{array}{c}\text { Normal Fine } \\
\text { Aggregate }\end{array}$ & $\begin{array}{c}\text { Normal } \\
\text { Coarse } \\
\text { Aggregate }\end{array}$ & $\begin{array}{c}\text { Recycled } \\
\text { Coarse } \\
\text { Aggregate }\end{array}$ \\
\hline Apparent specific gravity & 2.77 & 2.87 & 2.68 \\
Bulk specific gravity (dry) & 2.40 & 2.43 & 3.01 \\
Bulk specific gravity (SSD) & 2.53 & 2.45 & 2.43 \\
\% absorption of water & 6.78 & 7.46 & 7.97 \\
Weight of compact volume (kg/ltr) & 1.56 & 1.41 & 1.39 \\
Weight of loose volume (kg/ltr) & 1.40 & 1.28 & 1.23 \\
Maximum aggregate size (mm) & 4.75 & 25.00 & 25.00 \\
Fineness content (\%) & 2.20 & 0.70 & 0.10 \\
Fineness modulus & 2.40 & 6.50 & 4.564 \\
Water content (\%) & 12.30 & 1.39 & - \\
Soundness (\%) & 7.60 & 17.60 & 19.800 \\
Alkali Reactive & $\mathrm{Nil}$ & $\mathrm{Nil}$ & $\mathrm{Nil}$ \\
\% Abrasion & - & 23.40 & 31.20 \\
\hline
\end{tabular}

\subsection{Preparation of Specimens}


The first activity of concrete specimen testing is mix design in order to get a proportion of raw material such as fine and coarse aggregates, cement, and water. The proportion result can be seen in the Table 2 and 3.

Table 2. Raw material proportion of concrete for $25 \mathrm{MPa}$ compressive strength

\begin{tabular}{lccccc}
\hline \multirow{2}{*}{ Raw Materal } & $\begin{array}{c}\text { Normal } \\
\text { Concrete }\end{array}$ & $25 \%$ & $50 \%$ & $75 \%$ & $100 \%$ \\
\hline Cement & 413.46 & 413.46 & 413.46 & 413.46 & 413.46 \\
Water & 275,36 & 280,07 & 284,77 & 289.48 & 294,18 \\
Fine Aggregat & 617.31 & 617.31 & 617.31 & 617.31 & 617.31 \\
Coarse Aggregate & $1,073,86$ & 279.38 & 558.76 & 838.14 & $1,117.52$ \\
\hline
\end{tabular}

Note:Normal coarse aggregate content in the recycled concrete is depend on percentage of recycled aggregate content.

Table 3. Raw material proportion of concrete for $30 \mathrm{MPa}$ compressive strength

\begin{tabular}{lccccc}
\hline \multicolumn{1}{c}{ Raw Materal } & Normal & \multicolumn{4}{c}{ Recycled Concrete } \\
& Concrete & $25 \%$ & $50 \%$ & $75 \%$ & $100 \%$ \\
\hline Cement & 438.78 & 438.7 & 438.7 & 438.7 & 438.7 \\
Water & 224.88 & 227.93 & 230,97 & 234.02 & 237.07 \\
Fine Aggregat & 677,66 & 677,66 & 677,66 & 677,66 & 677,66 \\
Coarse Aggregater & $1,034,01$ & 269.01 & 538.02 & 807.03 & $1,076.04$ \\
\hline
\end{tabular}

The specimen of concrete is cylinder that dimension is dimeter $150 \mathrm{~mm}$ and height is $300 \mathrm{~mm}$. The testing of cylinder is crushing and indirect tensile (splitting) test. The crushing test will be compressed at $3,7,14,21$, and 28 ages, but splitting test is only at 28 age. The crushing test in the several age aims to monitor and check the development of concrete strength. Total number of specimens are 180 pieces.

The name of several specimens as above mention are:

- 25MPA-0 for normal concrete strength $25 \mathrm{MPa}$

- $25 \mathrm{MPA}-25$ for recycled aggregate content $25 \%$ in the concrete strength $25 \mathrm{MPa}$

- $25 \mathrm{MPA}-50$ for recycled aggregate content $50 \%$ in the concrete strength $25 \mathrm{MPa}$

- $25 \mathrm{MPA}-75$ for recycled aggregate content $75 \%$ in the concrete strength $25 \mathrm{MPa}$

- 25MPA-100 for recycled aggregate content $100 \%$ in the concrete strength $25 \mathrm{MPa}$

- 30MPA-0 for normal concrete strength $30 \mathrm{MPa}$

- $30 \mathrm{MPA}-25$ for recycled aggregate content $25 \%$ in the concrete strength $30 \mathrm{MPa}$

- $30 \mathrm{MPA}-50$ for recycled aggregate content $50 \%$ in the concrete strength $30 \mathrm{MPa}$

- $30 \mathrm{MPA}-75$ for recycled aggregate content $75 \%$ in the concrete strength $30 \mathrm{MPa}$

- 30MPA-100 for recycled aggregate content $100 \%$ in the concrete strength $30 \mathrm{MPa}$

\subsection{Equipment Devices}

The equipment devices of the testing is compressive test machine (Figure 3) and splitting apparatus (Figure 4). Those equipment are available in the Wiralodra University of Civil Laboratory. 


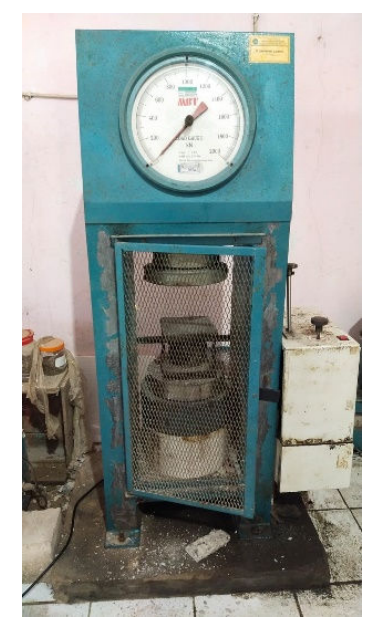

Fig. 3. Concrete compressive test

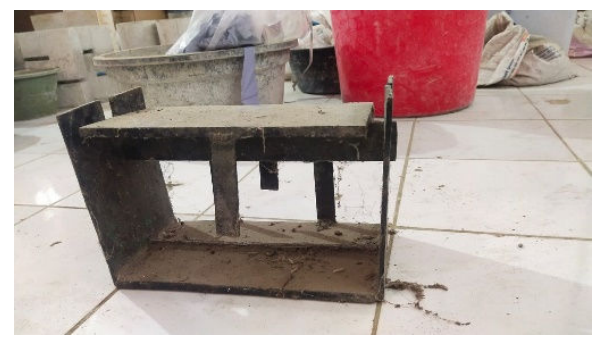

Fig. 4. Splitting test apparatus

\section{Test Result and Discussion}

\subsection{Compressive strength of concrete}

Crushing test of specimen that is cylinder shape as above dimension explanation will be tested under the compressive testing machine (Figure 3) until crush and record the final pressure indicator. The values of concrete compressive strength in the table are average result for three samples testing. The test result will be presented in the Table 4 .

Compressive strength of recycled concrete result lower than normal concrete. Decreasing of strength may be caused by quality of recycled aggregate is lower the normal aggregate that is shown an abrasion test which the abrasion percentage value is number of crushed aggregate during los Angeles test. The percentage of abrasion value is higher than normal concrete. Compressive strength decreasing is about $1-17 \%$ for $25 \mathrm{MPa}$ and $10-18 \%$ for $30 \mathrm{MPa}$ (Figure $5)$. It can be seen that the more increase of the compressive concrete strength design, so it will be more great the decrease of compressive strength.

Table 4. Compressive strength result

\begin{tabular}{|c|c|c|c|c|c|c|}
\hline \multirow{2}{*}{ Concrete Type } & \multicolumn{5}{|c|}{ Testing Age } & \multirow{2}{*}{$\begin{array}{c}\% \\
\text { decreasing }\end{array}$} \\
\hline & 3 days & 7 days & 14 days & 21 days & 28 days & \\
\hline 25MPA-0 & 10.47 & 15.85 & 21.80 & 23.92 & 25.29 & \\
\hline 25MPA-25 & 9.72 & 14.53 & 19.91 & 23.44 & 25.01 & 1.11 \\
\hline 25MPA-50 & 9.62 & 13.68 & 18.49 & 21.80 & 23.02 & 8.98 \\
\hline 25MPA-75 & 9.34 & 12.74 & 17.93 & 21.17 & 22.27 & 11.94 \\
\hline 25MPA-100 & 8.96 & 12.36 & 16.99 & 19.34 & 21.04 & 16.81 \\
\hline 30MPA-0 & 13.21 & 21.31 & 26.70 & 29.88 & 31.89 & \\
\hline 30MPA-25 & 10.57 & 17.65 & 23.67 & 27.11 & 28.63 & 10.22 \\
\hline 30MPA-50 & 9.83 & 16.65 & 22.87 & 26.01 & 27.86 & 12.64 \\
\hline 30MPA-75 & 9.40 & 15.89 & 22.27 & 25.76 & 26.95 & 15.49 \\
\hline
\end{tabular}




\begin{tabular}{lcccccc}
\hline \multirow{2}{*}{ Concrete Type } & \multicolumn{3}{c}{ Testing Age } & \multicolumn{2}{c}{ \% } \\
& 3 days & 7 days & 14 days & 21 days & 28 days & decreasing \\
\hline 30MPA-100 & 8.96 & 15.34 & 21.12 & 24.56 & 26.26 & 17.65 \\
\hline
\end{tabular}

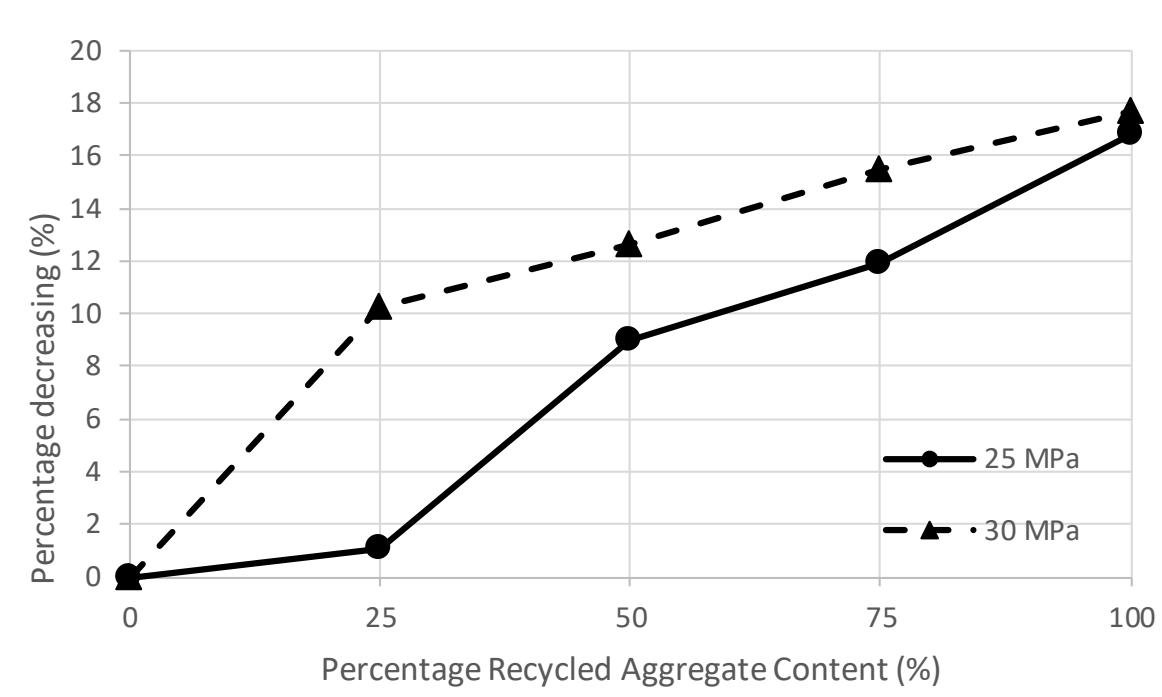

Fig. 5. Percentage decreasing of concrete compressive strength

\subsection{Tensile strength of concrete}

Tensile test of specimen that is cylinder shape as a compressive strength specimen will be tested under the indirect tensile testing machine (splitting apparatus testing) (Figure 4) until split and record the final pressure indicator. The values of concrete tensile strength in the table are average result for three samples testing. The test result will be presented in the Table 5.

Similar with compressive strength, the tensile strength of recycled concrete result lower than normal concrete. It also may be caused by quality of recycled aggregate is lower the normal aggregate. Tensile strength decreasing is about $2-13 \%$ for $25 \mathrm{MPa}$ and $7-22 \%$ for $30 \mathrm{MPa}$ (Figure 6). It can be seen that the increasing of the tensile concrete strength design will be greater the compressive strength decrease.

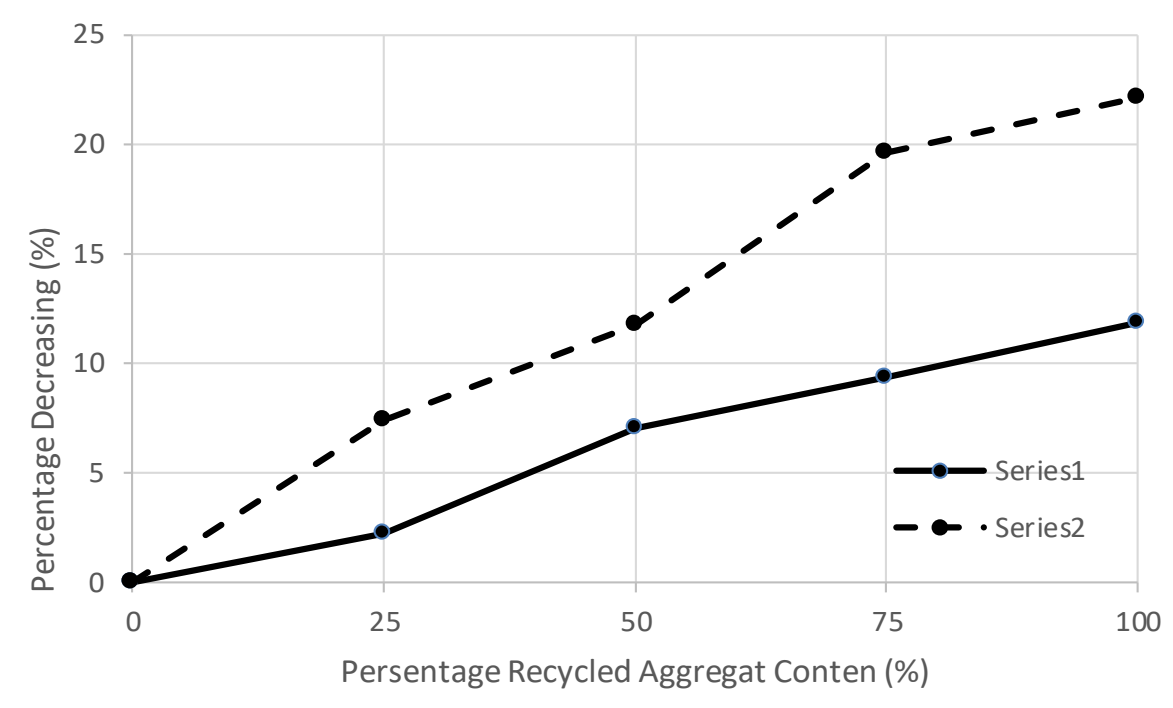

Fig. 6. Percentage decreasing of concrete tensile strength 
Table 5. Tensile strength result

\begin{tabular}{lccccc}
\hline \multicolumn{1}{c}{ Description } & & \multicolumn{5}{c}{ Concrete Compressive Strength 25 MPa } \\
Concrete Type & 25MPA-0 & 25MPA-25 & 25MPA-50 & 25MPA-75 & 25MPA-100 \\
\hline Tensile Strength (MPa) & 3.96 & 3.87 & 3.68 & 3.59 & 3.49 \\
$\%$ decreasing & & 2.27 & 7.07 & 9.34 & 11.87 \\
\hline \multicolumn{1}{c}{ Description } & & Concrete Compressive Strength 30 MPa & \\
Concrete Type & 30MPA-0 & 30MPA-25 & 30MPA-50 & 30MPA-75 & 30MPA-100 \\
\hline Tensile Strength (MPa) & 4.34 & 4.02 & 3.83 & 3.49 & 3.38 \\
$\%$ decreasing & & 7.37 & 11.75 & 19.59 & 22.12 \\
\hline
\end{tabular}

\section{Conclusion}

The concrete specimens testing have been done they are compressive and tensile test. The conclusion from the results of testing are :

1. Recycled aggregate that takes from concrete railway sleeper waste can be used as raw material of concrete, because the recycled aggregate specification can meet to the standar of ASTM. The deference of specifications are on the percentage absorption and abrasion that the values are greater than normal aggregate. They are caused more porosity in the recycled aggregate that affected of the mortar is still adhere around the existing normal aggregate of the recycled aggregate.

2. Decreasing percentage of recycled concrete compressive strength will be greater when the design of compressive strength of concrete is also increase. It may be caused by internal bonding or interlocking.

3. Similar with compressive concrete strength, the tensile strength also decrease. Percentage of recycled concrete tensile strength also will be greater when the design of compressive strength of concrete is increase.

\section{Acknowledgements}

This research has been done successfully, so researches aim to say Wiralodra University that has provided a laboratory and other facility such as room, equipment and others..

\section{References}

[1] ASTM C136-06/C136M-14 (2006), Sieve Analysis of Fine and Coarse Aggregates, ASTM Standards.

[2] Bardosono, H. and Herbudiman, B. (2010), Utilization of Recycled Concrete as a Substitute for Coarse Aggregate of High-Strength Concrete, National Conf. of Civil Eng., 4 (in Indonesian).

[3] Dabhade, A.N., Dr. Choudhari, S.R., Dr. Gajbhiye A.R. (2012), Performance Evaluation Of Recycled Aggregate Used In Concrete, IJERA 2(4): 1387-1391.

[4] Dhir, R.K., Limbachiya, M.C. and Leelawat, T. (1999), Suitability of Recycled Concrete Aggregate for Use in BS 5328 Designated Mixes, Proc. of Civil Engg. Struct. Build, 134: 257-274.

[5] Emad, M., Candidate, Soliman. N. M, Bashandy, A.A. (2019), Recycled Aggregate HighStrength Concrete, International Journal of Civil Engineering and Technology (IJCIET), 10(9), 128-146.

[6] Etxeberria, M., Vázquez, E., Marí, A., Barra, M. (2007), Influence of Amount of Recycled Coarse Aggregates and Production Process on Properties of Recycled Aggregate Concrete. Cem. Concr. Res. 37, 735-742 
[7] Fathei Ramadan Salehlamein, F. R., Solikin, M., Sunarjono, S. (2105), Effect of Recycled Coarse Aggregate on Concrete Properties, International Journal of Innovative Research in Science, Engineering and Technology, 4.

[8] Gonzalez-Corominas, A., Etxeberria, M. \& Poon, Cs. (2017), Influence of the Quality of Recycled Aggregates on the Mechanical and Durability Properties of High Performance Concrete, Waste Biomass Valor 8, 1421-1432.

[9] Hay, W.W. (1982), Railroad Engineering, Second Edition. Wiley

[10] Hidayat, H. \& Rachmadi (2001), Railroad Engineering, Lecturer Note, Publisher of ITB. Bandung (in Indonesian).

[11] Kumutha, R. and Vijai, K. (2010), Strength of Concrete Incorporating Aggregates Recycled from Demolition, ARPN Journal of Engineering and Applied Sciences, 5(5): 64-71.

[12] Limbachiya, M. C., Leelawat, T., Dhir, R. K. (2000), Use of Recycled Concrete Aggregate in High Strength Concrete, Materials and Structures, 33, 574-580.

[13] Manish K.S. and Dilip K. (2014), Utilization of Construction and Demolished Waster Material in Concrete, GJESR, 1(4),22-26.

[14] Monish M., Vikas Srivastava, V. C. Agarwal and Rakesh Kumar (2013), Utilization of Demolished Waste as Fine Aggregate in Concrete, Journal Acad. Indus. Res., 1(7), 540542.

[15] Neville, A. M. (1997), Properties of Concrete. Longman, Fifth Edition

[16] Oikonomou, N. D. (2005), Recycled Concrete Aggregates, Cement and Concrete Composites, 27(2), 315-318.

[17] Padmini, A.K., Ramamurthy, K., Mathews, M.S. (2009), Influence of Parent Concrete on the Properties of Recycled Aggregate Concrete, Construction and Building Materials, 23, 829-836.

[18] Provisions of the Ministry Republic of Indonesia No.24 (2015), Standard of Railway Safety, Department of Transportation, Republic of Indonesia (in Indonesian).

[19] PJKA (2015), Indonesian Railways Archives. National Archives of the Republic of Indonesia (in Indonesian).

[20] PJKA. 1986. Railroad Construction Planning (PD No.10) Bandung (in Indonesian).

[21] Poon, C. S., Kou S. C., Lam, L. (2002), Use of Recycled Aggregates in Molded Concrete Bricks and Blocks, Construction and Building Materials, 16(5), 281-289

[22] Priyanka. K., Lavanya. G., Akila, P. (2019), A Review: Structural Optimization of Railway Sleepers by Replacing Fine Aggregate with Waste Materials, International Journal of Innovative Research in Technology, 6(5).

[23] Ratnawati, Y. (2015), The Development of Railways During the Colonial Period in Semarang in 1867-1901, Journal of Indonesian History, 3 (in Indonesian).

[24] Ravindrajah, R.S., Loo, Y.H., Tam, C.T. (1988), Strength Evaluation of Recycled Aggregate Concrete by In-situ Tests, Mater. Struct. 21, 289-295.

[25] Rusbintardjo, G. (2012), Textbook of Steel Road Construction, $1^{\text {st }}$ Print, Semarang UNISSULA Press (in Indonesian).

[26] S. Muthu Lakshmi, S. M. L., \& R. R. Nivedhitha, R. R. N. (2018), Effect Of Partial Replacement Of Aggregates By Recycled Concrete Debris On Strength Of Concrete, Malaysian Journal of Civil Engineering, 27(2).

[27] Sami W. Tabsh, Akmal S. Abdelfatah (2009), Influence of Recycled Concrete Aggregates on Strength Properties of Concrete, Construction and Building Materials, 23(2), 1163-1167

[28] Silva, R.V., De Brito, J., Dhir, R.K. (2014), Properties and Composition of Recycled Aggregates from Construction and Demolition Waste Suitable for Concrete Production, Constr. Build. Mater. 65, 201-217

[29] SNI 8828 (2019), Concrete Bearings and Fastening Systems for Rail Roads, Department of Industry, Republic of Indonesia (in Indonesian).

[30] Suharwanto (2004), Mechanical Properties of Recycle Concrete: Material and Structural Aspects, Disertation, Institut Teknologi Bandung (in Indonesian). 
[31] Tabsh, S.W., Abdelfatah, A.S. (2009), Influence of Recycled Concrete Aggregates on Strength Properties of Concrete, Constr. Build. Mater. 23, 1163-1167.

[32] Topçu, İ.B., Şengel, S. (2004), Properties of Concretes Produced with Waste Concrete Aggregate, Cem. Concr. Res. 34, 1307-1312.

[33] Wardhana, I. K. (2018). The Influence of the Use of Waste Concrete Coarse Aggregate on the Compressive Strength and Tensile Strength of Normal Concrete (in Indonesian).

[34] Xiao, J., Li, J., Zhang, C. (2005), Mechanical Properties of Recycled Aggregate Concrete under Uniaxial Loading, Cem. Concr. Res. 35, 1187-1194.

[35] Yadav, S. R. and Pathak, S. R. (2009), Use of Recycled Concrete Aggregate in Making Concrete, An Overview, Proceedings of 34th Conference on Our World in Concrete \& Structures, Singapore.

[36] Yusra A, Opirina, L. Irwansyah (2019), Effect of Artificial Aggregate Substitution (Recycled Concrete) on Normal Concrete Compressive Strength, Journal of Civil Eng., Universitas Teuku Umar, 5(1), 1 of 12 (in Indonesian). 